\title{
Physicochemical properties, antioxidant activities and sensory characteristics of commercial gape vinegars during long-term storage
}

\author{
Minjeong KANG ${ }^{1}$, Jung-Heun $\mathrm{HA}^{1}$, Youngseung LEE ${ }^{1 *}$
}

\begin{abstract}
This study was designed to investigate changes in quality characteristics during long-term storage of five commercial grape vinegars (V1 V5). To determine long-term quality characteristics of vinegars, proximate (soluble solid, $\mathrm{pH}$, total acidity, color, and antioxidant activity) and sensory descriptive analysis, were performed. Initial soluble solids were high in V4 and V5 (contained higher liquid fructose or grape concentrate), but after $12 \mathrm{mo}$ of storage, soluble solids decreased significantly in V4 and V5 (non-sterile products). Initial total acidity was close to the amount of additional juice, while V4 and V5 had increased total acidity after 12-mo storage. Browning was dominant in V4 and V5 regardless of storage periods. Initial DPPH radical scavenging activity was high for all samples, while it tended to decrease after 6-mo storage. In sensory descriptive analysis, browning and turbidity was markedly elevated during 12 -mo storage in general. Aromatic factors were significantly attenuated in all test samples during storage. Interestingly, V4 and V5 were considered as having lower sourness and bitterness since sweetness was stronger in these than in other samples due to the addition of liquid fructose. The results suggest that for optimal quality, commercial grape vinegars are best consumed within 6 mo of storage after opening.
\end{abstract}

Keywords: grape vinegar; long-term storage; quality characteristics; sensory evaluation.

Practical Application: Quality characteristics of commercial grape vinegars during long-term storage for up to 1 year.

\section{Introduction}

Vinegar is a well-known fermented food that has been used since ancient times in both east and west. Vinegars can be classified into grain and fruit types based on the raw materials used. Grain vinegars contain rice, wheat or other grains, while grapes, apples or other fruits are used to produce fruit vinegars (Chen et al., 2016). Vinegars are widely useful for medical and cosmetic purposes (Ashchyan et al., 2018). They have an alkali characteristic that decomposes lactic acid in body tissues and helps relieve fatigue (Atik et al., 2016; Choi et al., 2013), and the sour flavor promotes appetite, digestion and absorption (Jeong et al., 2011). In addition, vinegar promotes the excretion of sodium and silicic acid, and it is known to be effective in preventing or treating fever, swelling, stomach ache and metabolic complications, such as high blood pressure, atherosclerosis, insulin resistance, and hyperlipidemia (Budak et al., 2014; Ishak et al., 2018; Mitrou et al., 2015).

In a fruit vinegar market in Korea, the amount of fruit vinegars exported in the first half of 2017 was 2,572 tons, a noticeable $40.0 \%$ increase over the amount exported in the first half of 2016 (1837 tons). Taking the sales of drinking and seasoning vinegars in Korea into consideration, sale of drinking vinegar, including red vinegar, tended to decrease after 2014; however, sale of fruit vinegars for seasoning increased by $21.1 \%$ over the same period (Korea Agro-Fisheries and Food Trade Corporation, 2017).
Recently the vinegar brewing market has become more sophisticated and diversified due to the increasing demand for natural vinegar production from $100 \%$ fruits (Mo et al., 2013). Fruit vinegars are produced from sugar oxidization by alcohol fermentation (Mas et al., 2014). Currently, Korean fruit vinegar is produced by three methods: 1) mixing fruit with inorganic salt, diluted ethanol and $30 \%$ of fruit juice, 2) two-stage, alcohol and acetic acid, fermentation from intact fruit or 3) fermentation with fungus (Jeoung \& Lee, 2000).

The quality of vinegar depends on fermentation, production methods, raw materials, and additives used. In addition, the acetic acid content, odor component, and organic acid and free amino acid composition affects the quality of vinegar. In particular, fruit vinegar contains various sugars since it is produced by fermentation of the liquid-containing fruit juice (Liu et al., 2019; Roda et al., 2017). Vinegar contains glucose mostly and also has fructose, sucrose, maltose, and other sugars, which affect its sweetness (Kim et al., 2010a).

Like other food products, vinegars also suffer oxidation after being opened. Oxidation processes promote a series of chemical and enzymatic reactions that alter vinegar (Casale et al., 2006). Therefore, oxygen is the main cause of vinegar quality deterioration. Alterations in appearance and color, such as turbidity problems and precipitation that may occur during storage or retail may reduce the product quality. Therefore, it is necessary to study changes in vinegar quality due to storage time and temperature as this type 
of study will provide essential information for maintaining robust storage stability of vinegar (Casale et al., 2006).

Recent research trends in commercially available vinegar have mainly focused on the properties and biological effects: 1) comparison of the physicochemical quality and aroma of commercial fruit vinegar (Kim et al., 2010b), 2) comparison of the acidity characteristics of commercial cider vinegar (Jo et al., 2012) and 3) observation and improvement of the oxidation of vinegar during storage using NIR (Casale et al., 2006), 4) antioxidant activity of commercial vinegar during domestic use (Lee et al., 2009), 5) weight loss (Beh et al., 2017; Halima et al., 2018), 6) anti-inflammatory (Beh et al., 2017; Mohamad et al., 2017), and 7) improving glucose sensitivity (Petsiou et al., 2014; Seo et al., 2014) effects of vinegar in obese and/or diabetic subjects. However, there is an information gap in vinegar quality changes due to storage period. Therefore, in this study, five representative varieties of commercially available grape vinegar products were selected, and alterations in physicochemical properties, antioxidant activity, and sensory characteristics were investigated for $12 \mathrm{mo}$.

\section{Materials and methods}

\subsection{Samples and storage test}

Five different brands of grape vinegars (V1 [Oenopia, Hwaseong, Korea], V2 [Cholove, Chungju, Korea], V3 [Vineko, Pocheon, Korea], V4 [Daesang, Seoul, Korea], and V5 [Sempio, Seoul, Korea)]), with similar production and expiration (2-year) dates were purchased in December, 2017 (Table 1).

\subsection{Soluble solid, $\mathrm{pH}$ and total acidity}

Soluble solids were measured in ${ }^{\circ}$ Brix using a refractometer (Master-M, ATAGO, Tokyo, Japan). pH was measured using a pH meter (model 720A, Orion Research Inc, Boston, MA, USA). Total acidity was converted to the acetate content (\%) after 4-fold diluted samples were neutralized with $0.1 \mathrm{~N} \mathrm{NaOH}$ solution, using phenolphthalein as an indicator. All measurements were in triplicates.

\subsection{Browning value}

The browning color was measured in 200-fold diluted samples at 280 and $290 \mathrm{~nm}$ using a spectrophotometer (Agilent Technologies, Santa Clara, USA). All measurements were in triplicates.

\subsection{Assessment of anti-oxidation activity}

DPPH and FRAP assay were performed for analyzing antioxidative activities in the sample (Mensor et al., 2001). The DPPH (2.2-diphenyl-1-picrylhydrazyl) radical scavenging activity of vinegar was determined by mixing $0.1 \mathrm{~mL}$ of vinegar and $1.2 \mathrm{~mL}$ of $0.2 \mathrm{mM} \mathrm{DPPH}$ in a dark room at room temperature for $30 \mathrm{~min}$ and measuring the absorbance at $517 \mathrm{~nm}$ using a spectrophotometer. It was then calculated via the following Equation 1 and expressed as a percentage (\%) (Thaipong et al., 2006).

DPPH radical removal activity $(\%)=$

$[1$ - (absorbance of sample / absorbance of control $)] \times 100$

Ferric reducing antioxidant power (FRAP) was determined by adding $0.05 \mathrm{~mL}$ vinegar to $1.3 \mathrm{~mL}$ FRAP solution, reacting the mixture at $37^{\circ} \mathrm{C}$ for $30 \mathrm{~min}$, then measuring the absorbance at $573 \mathrm{~nm}$ using a spectrophotometer with a standard curve generated with ascorbic acid. After establishment of the standard curve, the FRAP content was indicated as mg ascorbic acid in $1 \mathrm{~mL}$ vinegar (Thaipong et al., 2006). All measurements were in triplicates.

\subsection{Descriptive analysis}

A descriptive analysis by eight panelists (aged 20's; 2 males, and 6 females) with $\geq 50 \mathrm{~h}$ experience conducted to evaluate the characteristics of the main sensory attributes of grape vinegars, such as appearance, aroma, flavor and texture. The descriptive analysis was carried out according to Institutional Review Board (IRB) procedure after receiving IRB approval (approval number: DKU 2018-01-006) at the Dankook University Bioethics Committee. The order of providing and evaluating the samples was repeated twice, and the order of sample serving was randomly presented across panelists. The attributes evaluated include appearance (browning), aroma (grape aroma, caramel aroma, alcohol aroma, yeast aroma, nuruk aroma), flavor (sweetness, sourness, bitterness, yeast flavor, nuruk flavor, balance), and texture (teobteobhan-mat, viscosity, body, burning sensation). The intensity of each sensory attribute was measured using a 16-point scale ( 0 to 15 points). Reference samples that best represent the sensory characteristics established were prepared in various forms according to (Torri et al., 2017). Samples were provided in a transparent $10 \mathrm{~mL}$ glass bottle, and the aroma was

Table 1. Descriptions of commercial grape vinegar used in this study.

\begin{tabular}{|c|c|}
\hline Sample & Description \\
\hline $\mathrm{V} 1$ & Grape 99\% (Cambell Early 100\%, from Korea), yeast $0.02 \%$, antioxidant agent $0.01 \%$ (sulfur dioxide) \\
\hline $\mathrm{V} 2$ & Grape $90 \%$ (Cambell Early 100\%, from Korea), sucrose $9.9 \%$, yeast $0.025 \%$ \\
\hline $\mathrm{V} 3$ & Red wine $80 \%$ (Cambell Early 100\%, from Korea), vinegar starter 20\% \\
\hline V4 & $\begin{array}{l}\text { Balsamic vinegar } 35 \% \text { \{wine vinegar (from Italy), grape concentrate } 25 \% \text { (from Italy), antioxidant agent (sulfur dioxide) }\} \text {, red grape } \\
\text { concentrate } 23 \% \text { (red grape } 100 \% \text {, from Italy, } 65^{\circ} \mathrm{Brix} \text { ), purified water, balsamic flavor base }\{\text { liquid fructose, red wine flavor, citric acid, } \\
\text { hydrolyzed glucose, malt extract (barley: from Germany), synthetic flavor (sweet flavor) }\} \text {, liquid fructose, oligosaccharide, main alcohol, } \\
\text { malic acid, red wine flavor, synthetic flavor (balsamic flavor), yeast extract }\end{array}$ \\
\hline V5 & Wine vinegar (grape $100 \%$, from Italy), grape concentrate $33 \%$ (grape $100 \%, 64.7^{\circ} \mathrm{Brix}$ ), from Italy) \\
\hline
\end{tabular}


assessed using a brown $10 \mathrm{~mL}$ glass bottle to minimize any clue coming from appearance. Flavor and texture were evaluated by placing the sample in a spuit and placing it in a $180-\mathrm{mL}$ paper cup with a three-spot random cord attached, and placing 2 to 3 drops on a spoon. Since the sample to be evaluated is irritating, such that sensory fatigue and cross effect of samples may occur, one sample was evaluated and the mouth was rinsed sufficiently with water before the next sample was evaluated. All assessments were conducted independently in separate sensory booths.

\subsection{Statistical analysis}

Results were analyzed by two-way ANOVA using XLSTAT software version 2012 for windows (Addinsoft Inc., Paris, France), followed by Tukey's post-hoc test and significance was assessed at 5\% level. Sample and storage period were treated as main factors, while significant interactions between sample and storatge period were also investigated. Principal component analysis (PCA) was performed using mean values for each of the sensory characteristics of the samples to allow explaining the differences in sensory properties between the samples.

\section{Results and discussion}

\subsection{Soluble solid, $\mathrm{pH}$ and total acidity}

Table 2 shows the changes in soluble solids, $\mathrm{pH}$, and total acidity of the five vinegars during 12 -mo storage.

Soluble solids, which are influenced by additives in vinegar, consist of free sugars, such as glucose, fructose and sucrose, organic acids and free amino acids (Chen et al., 2009). (Kim et al., 2010a) reported the free sugar contents of commercial vinegars and found different levels of free sugar contents depending on the type of fruit they were sourced from. Grape vinegar had the highest fructose content, but the correlation between total solids and free sugar contents was not statistically significant (data not shown). The total solids content of vinegar is due to the presence of trace elements such as organic acids and free amino acids.

V4 and V5 contained significantly higher soluble solids than others by 4 to 6 times. As aforementioned, since the free sugar contents of the commercial grape vinegars did not affect the total solids content, the higher solid contents in V4 and V5 may be due to the addition of liquid fructose and grape concentrate (V4: 48\% and V5: 33\%) during processing (refer to Table 1). Addition of liquid fructose and grape concentrate to commercial vinegar was reported to increase consumer's preference by elevating sugar content (Yang \& Rho, 2012).

Changes in the soluble solid contents of samples according to the storage period were markedly different depending on whether products were sterilized or not. The soluble solid content of non-sterilized products (V4 and V5) tended to decrease in general, but was not significantly altered in sterilized products (V1, V2 and V3) during storage (Table 2). A possible reason for the decrease in solid contents of non-sterilized products is that acetic acid bacteria, present in the products, could decompose free sugar continuously after the product was opened. Therefore, the total acidity of non-sterilized products might increase after 12 mo of storage. On the other hand, sterilized products possibly retained their initial solid contents and total acidity due to the deactivation of acetic acid bacteria by sterilization.

The $\mathrm{pH}$ of commercially available grape vinegar widely ranged from 2.36 to 3.00 , depending on the type of vinegar (Table 2). $\mathrm{pH}$ tended to decrease in most samples during the storage period, mainly due to the amount of organic or total acids present in the vinegar (Liu et al., 2008). Table 2 shows that $\mathrm{pH}$ and total acid content of the vinegars were not inversely correlated during storage. It is presumable that the decay rates of free sugars and amino acids were different among the vinegars.

Table 2. Soluble solid, $\mathrm{pH}$ and total acidity of grape vinegars during storage.

\begin{tabular}{|c|c|c|c|c|c|c|}
\hline & \multirow{2}{*}{ Sample } & \multicolumn{5}{|c|}{ Storage time (month) } \\
\hline & & 0 & 3 & 6 & 9 & 12 \\
\hline \multirow{5}{*}{$\begin{array}{l}\text { Soluble solid } \\
\left({ }^{\circ} \text { Brix }\right)\end{array}$} & $\mathrm{V} 1$ & $8.30 \pm 0.79_{\mathrm{D}}^{\mathrm{a} 1) 22}$ & $7.20 \pm 0.12_{\mathrm{D}}^{\mathrm{b}}$ & $7.13 \pm 0.12_{\mathrm{D}}^{\mathrm{b}}$ & $7.07 \pm 0.12_{D}{ }^{b}$ & $7.13 \pm 0.14_{D}{ }^{b}$ \\
\hline & V2 & $6.13 \pm 0.23_{\mathrm{E}}^{3{ }^{3 a}}$ & $5.97 \pm 0.06_{\mathrm{E}}^{\mathrm{a}}$ & $5.87 \pm 0.212_{\mathrm{E}}^{\mathrm{a}}$ & $5.97 \pm 0.06_{\mathrm{E}}^{\mathrm{a}}$ & $5.87 \pm 0.12_{\mathrm{E}}^{\mathrm{a}}$ \\
\hline & V3 & $9.53 \pm 012_{\mathrm{C}}^{\mathrm{ab}}$ & $9.80 \pm 0.23_{C}{ }^{a}$ & $9.27 \pm 0.12_{\mathrm{C}}^{\mathrm{b}}$ & $9.13 \pm 0.12_{\mathrm{C}}^{\mathrm{b}}$ & $9.33 \pm 0.14_{C}{ }^{b}$ \\
\hline & V4 & $38.67 \pm 0.58_{\mathrm{A}}{ }^{\mathrm{a}}$ & $37.67 \pm 0.58_{\mathrm{A}}^{\mathrm{ab}}$ & $38.00 \pm 0.00_{\mathrm{A}}^{\mathrm{ab}}$ & $37.53 \pm 0.12_{\mathrm{A}}^{\mathrm{b}}$ & $38.60 \pm 0.06_{\mathrm{A}}^{\mathrm{a}}$ \\
\hline & V5 & $32.67 \pm 0.58_{\mathrm{B}}{ }^{\mathrm{a}}$ & $31.67 \pm 0.58_{\mathrm{B}}^{\mathrm{ab}}$ & $30.67 \pm 0.58_{\mathrm{B}}^{\mathrm{b}}$ & $30.73 \pm 0.31_{\mathrm{B}}^{\mathrm{b}}$ & $31.00 \pm 0.00_{\mathrm{B}}^{\mathrm{b}}$ \\
\hline \multirow{4}{*}{$\mathrm{pH}$} & $\mathrm{V} 2$ & $2.96 \pm 0.03_{\mathrm{A}}^{\mathrm{ab}}$ & $3.00 \pm 0.01_{\mathrm{A}}^{\mathrm{a}}$ & $2.93 \pm 0.02_{\mathrm{A}}^{\mathrm{bc}}$ & $2.74 \pm 0.00_{B}{ }^{\mathrm{d}}$ & $2.88 \pm 0.02_{\mathrm{A}}{ }^{\mathrm{c}}$ \\
\hline & V3 & $2.98 \pm 0.02_{\mathrm{A}}{ }^{\mathrm{a}}$ & $2.92 \pm 0.02_{\mathrm{B}}^{\mathrm{b}}$ & $2.74 \pm 0.02_{B}{ }^{\mathrm{d}}$ & $2.58 \pm 0.00_{\mathrm{D}}^{\mathrm{e}}$ & $2.78 \pm 0.02_{\mathrm{B}}^{\mathrm{c}}$ \\
\hline & $\mathrm{V} 4$ & $2.59 \pm 0.02_{\mathrm{C}}{ }^{\mathrm{a}}$ & $2.62 \pm 0.01_{D}{ }^{a}$ & $2.52 \pm 0.02_{C}{ }^{b}$ & $2.36 \pm 0.25_{\mathrm{E}}^{\mathrm{d}}$ & $2.47 \pm 0.02_{\mathrm{C}}{ }^{\mathrm{c}}$ \\
\hline & V5 & $2.98 \pm 0.03_{\mathrm{A}}{ }^{\mathrm{a}}$ & $3.00 \pm 0.01_{\mathrm{A}}^{\mathrm{a}}$ & $2.89 \pm 0.01_{\mathrm{A}}^{\mathrm{b}}$ & $2.77 \pm 0.01_{\mathrm{A}}{ }^{\mathrm{c}}$ & $2.90 \pm 0.00_{\mathrm{A}}^{\mathrm{b}}$ \\
\hline \multirow{2}{*}{$\begin{array}{l}\text { Total acidity } \\
(\%)\end{array}$} & V1 & $5.74 \pm 0.08_{\mathrm{B}}^{\mathrm{ab}}$ & $5.67 \pm 0.04_{\mathrm{B}}^{\mathrm{b}}$ & $5.85 \pm 0.06_{\mathrm{C}}^{\mathrm{a}}$ & $5.77 \pm 0.05_{\mathrm{B}}^{\mathrm{ab}}$ & $5.81 \pm 0.05_{\mathrm{C}}^{\mathrm{ab}}$ \\
\hline & V5 & $6.25 \pm 0.18_{\mathrm{A}}^{\mathrm{ab}}$ & $6.32 \pm 0.06_{\mathrm{A}}^{\mathrm{a}}$ & $6.18 \pm 0.06_{\mathrm{B}}^{\mathrm{ab}}$ & $6.11 \pm 0.06_{\mathrm{A}}^{\mathrm{ab}}$ & $6.01 \pm 0.06_{\mathrm{B}}^{\mathrm{b}}$ \\
\hline
\end{tabular}

Product codes are the same as in Table $1 .{ }^{1)}$ Mean \pm standard deviation; ${ }^{2) a-d}$ Means with different superscript in the same row for each samples are significantly different $(\mathrm{p}<0.05)$;

${ }^{3) \mathrm{A} \sim \mathrm{E}}$ Means with different subscripts in the same column for each samples are significantly different $(\mathrm{p}<0.05)$. 
As a result of total acidity measurement (Table 2), V2 and V5 were the highest at 6.05 and $6.25 \%$, respectively. Total acid contents are usually influenced by either fermentation or addition of grape concentrates (Goswami \& Ray, 2011), and these may be responsible for the differences in total acid contents among vinegars. The change in total acidity with storage tended to increase in non-sterilized products, which seemed to be consistent with a previous study by (Hutchinson et al., 2019), where acetic acid produced by the action of acetic acid bacteria in non-sterile products were found to determine the total acid content.

\subsection{Browning value and antioxidant activities of grape vinegars}

According to (Liu et al., 2008), the vinegar color is influenced by various factors, including the color of raw materials, chemical reactions during preparation, pigment produced by chemical or enzymatic reactions during fermentation, and the addition of caramel colorants, etc. Following initial browning (Table 3), V4 (0.59) and V5 (1.7) initially showed the highest browning, while V2 and V3 showed the lowest.

This result was probably due to the higher fructose or grape concentrates intentionally added to V4 and V5. Oh et al. (2017) reported that grape concentrates produced browning intermediates, such as hydroxymethyl-furfural (HMF) and furfural, that were not present in squeezed grape during the manufacturing process. HMF is produced by the Maillard reaction, a representative nonenzymatic browning reaction (Leiva et al., 2017). During the entire storage period, V4 and V5 exhibited stronger intensities of brownness than other products. Browning substances in the grape concentrates contained in V4 and V5 might decrease brightness.

The browning of vinegars during storage is also influenced by enzymatic browning by polyphenol oxidase or ascorbic acid oxidation by oxygen during storage. After 3 mo of storage, browning tended to increase regardless of vinegar type. Browning might increase in non-sterilized products (V1, V2, and V3) by oxidation of resveratrol, a substrate of polyphenol oxidase in grape, to quinone, which produces the melanin pigment of brown substances through polymerization and condensation (Ma \& Waterhouse, 2018). On the other hand, browning may increase in sterilized products (V4 and V5) by polymerization reaction of ascorbic acid in grape or condensation reaction of free amino acids. Ascorbic acid is normally used to prevent oxidation and browning; however, once ascorbic acid is irreversibly oxidized, browning is accelerated due to increasing oxidative by-products (Li et al., 2008).

Oxidation of grape vinegars could be inhibited by citric acid present in the grape or by adding anhydrous sulfuric acid. Citric acid and anhydrous sulfuric acid are known to act as antioxidants in vinegar due to their oxidative catalysis and enzymatic inactivation (Ali et al., 2015). In this study, sulfur dioxide may decrease by the decomposition of citric and anhydrous sulfuric acids due to the reaction between oxygen and vinegars since the vinegars were stored after opening (Casale et al., 2006). The decomposition of sulfur dioxide in vinegar has been reported to cause the precipitation of insoluble substances by reacting on peroxidase activity and tannic compounds which alter the color and flavor of vinegar (Casale et al., 2006). Therefore, browning observed in all five vinegars might be due to oxidation during the storage period.

Table 3 represents the DPPH radical scavenging activity and FRAP assay results of the samples. V1 and V4 initially (0 mo) showed significantly higher DPPH radical scavenging activity of $85.75 \%$ and $84.60 \%$, respectively. This was because V1 was aged in oak barrels for a certain period of time, and the total phenolic content increased accordingly due to the extraction of

Table 3. Browning value, DPPH radical scavenging activity and FRAP of grape vinegars during storage.

\begin{tabular}{|c|c|c|c|c|c|c|}
\hline & \multirow{2}{*}{ Sample } & \multicolumn{5}{|c|}{ Storage time (month) } \\
\hline & & 0 & 3 & 6 & 9 & 12 \\
\hline \multirow{5}{*}{$\begin{array}{l}\text { Browning } \\
(290 \mathrm{~nm})\end{array}$} & $\mathrm{V} 1$ & $0.28 \pm 0.01_{C}^{b c 1) 2)}$ & $0.27 \pm 0.01_{C}^{c}$ & $0.31 \pm 0.02_{C}^{a b c}$ & $0.34 \pm 0.01_{C}^{a}$ & $0.31 \pm 0.00_{\mathrm{C}}^{\mathrm{ab}}$ \\
\hline & $\mathrm{V} 2$ & $\left.0.17 \pm 0.01_{D}^{3}\right)^{3 b c}$ & $0.17 \pm .0 .00_{\mathrm{CD}}^{c}$ & $0.21 \pm 0.01_{D}^{a}$ & $0.20 \pm 0.01_{\mathrm{D}}^{\mathrm{ab}}$ & $0.21 \pm 0.01_{D}^{a}$ \\
\hline & $\mathrm{V} 3$ & $0.11 \pm 0.01_{\mathrm{D}}^{\mathrm{b}}$ & $0.11 \pm 0.00_{\mathrm{D}}^{\mathrm{b}}$ & $0.13 \pm 0.01_{\mathrm{E}}^{\mathrm{ab}}$ & $0.14 \pm 0.00_{\mathrm{D}}^{\mathrm{ab}}$ & $0.14 \pm 0.00_{\mathrm{D}}^{\mathrm{a}}$ \\
\hline & $\mathrm{V} 4$ & $0.59 \pm 0.05_{\mathrm{B}}^{\mathrm{b}}$ & $0.53 \pm 0.03_{\mathrm{B}}^{\mathrm{b}}$ & $0.61 \pm 0.01_{B}^{b}$ & $0.72 \pm 0.04_{\mathrm{B}}^{\mathrm{a}}$ & $0.73 \pm 0.04_{\mathrm{B}}^{\mathrm{a}}$ \\
\hline & V5 & $1.70 \pm 0.04_{\mathrm{A}}^{\mathrm{b}}$ & $1.63 \pm 0.08_{\mathrm{A}}^{\mathrm{b}}$ & $1.79 \pm 0.03_{\mathrm{A}}^{\mathrm{ab}}$ & $1.93 \pm 0.10_{\mathrm{A}}{ }^{\mathrm{a}}$ & $1.96 \pm 0.05_{\mathrm{A}}^{\mathrm{a}}$ \\
\hline \multirow[t]{5}{*}{ DPPH (\%) } & $\mathrm{V} 1$ & $85.75 \pm 0.02_{\mathrm{A}}^{\mathrm{b} 1) 2)}$ & $82.87 \pm 0.02_{\mathrm{A}}^{\mathrm{bc}}$ & $89.04 \pm 0.00_{\mathrm{A}}^{\mathrm{a}}$ & $80.93 \pm 0.03_{\mathrm{A}}{ }^{\mathrm{c}}$ & $85.47 \pm 0.01_{\mathrm{A}}^{\mathrm{b}}$ \\
\hline & $\mathrm{V} 2$ & $52.12 \pm 0.01_{\mathrm{D} 3)}^{\mathrm{b}}$ & $35.76 \pm 0.02_{\mathrm{C}}{ }^{\mathrm{c}}$ & $56.12 \pm 0.03_{\mathrm{D}}^{\mathrm{a}}$ & $57.78 \pm 0.03_{\mathrm{C}}^{\mathrm{a}}$ & $56.11 \pm 0.03_{\mathrm{C}}^{\mathrm{a}}$ \\
\hline & V3 & $59.63 \pm 0.04_{C}^{a}$ & $52.26 \pm 0.04_{\mathrm{B}}^{\mathrm{b}}$ & $65.43 \pm 0.02_{C}^{a}$ & $51.87 \pm 0.04_{D}^{b}$ & $61.95 \pm 0.05_{\mathrm{C}}^{\mathrm{a}}$ \\
\hline & V4 & $84.60 \pm 0.01_{\mathrm{A}}{ }^{\mathrm{a}}$ & $77.97 \pm 0.01_{\mathrm{A}}^{\mathrm{bc}}$ & $78.81 \pm 0.02_{\mathrm{B}}^{\mathrm{b}}$ & $75.17 \pm 0.03_{\mathrm{B}}{ }^{\mathrm{c}}$ & $78.44 \pm 0.03_{\mathrm{B}}^{\mathrm{bc}}$ \\
\hline & V5 & $66.11 \pm 0.06_{\mathrm{B}}^{\mathrm{a}}$ & $52.97 \pm 0.03_{\mathrm{B}}{ }^{\mathrm{c}}$ & $64.01 \pm 0.05_{\mathrm{C}}^{\mathrm{ab}}$ & $61.57 \pm 0.03_{\mathrm{C}}^{\mathrm{ab}}$ & $58.35 \pm 0.07{ }_{C}^{b c}$ \\
\hline \multirow[t]{5}{*}{ FRAP (AEmg/mL) } & $\mathrm{V} 1$ & $5.12 \pm 0.06_{\mathrm{B}}^{\mathrm{a}}$ & $3.17 \pm 0.03_{\mathrm{C}}^{c}$ & $3.34 \pm 0.04_{\mathrm{B}}{ }^{\mathrm{c}}$ & $4.43 \pm 0.09_{\mathrm{C}}^{\mathrm{b}}$ & $3.31 \pm 0.08_{\mathrm{C}}{ }^{\mathrm{c}}$ \\
\hline & $\mathrm{V} 2$ & $2.55 \pm 0.08_{\mathrm{C}}{ }^{\mathrm{a}}$ & $1.46 \pm 0.02_{\mathrm{D}}^{\mathrm{b}}$ & $1.58 \pm 0.04_{C}^{b}$ & $2.78 \pm 0.03_{\mathrm{D}}^{\mathrm{a}}$ & $1.79 \pm 0.07_{\mathrm{D}}^{\mathrm{b}}$ \\
\hline & $\mathrm{V} 3$ & $2.65 \pm 0.03_{\mathrm{C}}^{\mathrm{a}}$ & $1.54 \pm 0.05_{D}^{c}$ & $1.72 \pm 0.03_{\mathrm{C}}^{c}$ & $2.32 \pm 0.03_{\mathrm{D}}^{\mathrm{b}}$ & $1.80 \pm 0.09_{\mathrm{D}}^{\mathrm{c}}$ \\
\hline & V4 & $5.79 \pm 0.07_{\mathrm{A}}^{\mathrm{b}}$ & $4.95 \pm 0.01_{\mathrm{A}}^{\mathrm{bc}}$ & $4.74 \pm 0.38_{\mathrm{A}}{ }^{\mathrm{c}}$ & $6.95 \pm 0.09_{\mathrm{A}}^{\mathrm{a}}$ & $5.59 \pm 0.09_{\mathrm{A}}^{\mathrm{bc}}$ \\
\hline & V5 & $5.35 \pm 0.03_{\mathrm{AB}}^{\mathrm{b}}$ & $3.37 \pm 0.03_{B}{ }^{d}$ & $3.77 \pm 0.10_{B}{ }^{d}$ & $6.14 \pm 0.10_{\mathrm{B}}{ }^{\mathrm{a}}$ & $4.25 \pm 0.02_{\mathrm{B}}{ }^{\mathrm{c}}$ \\
\hline
\end{tabular}

Product codes are the same as in Table $1 .{ }^{1)}$ Mean \pm standard deviation; ${ }^{2) a}$ d Means with different superscript in the same row for each samples are significantly different $(\mathrm{p}<0.05)$;

${ }^{3) \mathrm{A} \sim \mathrm{E}}$ Means with different subscripts in the same column for each samples are significantly different $(\mathrm{p}<0.05)$. 
phenolic compounds from the oak tree wood during the aging process (Zhang et al., 2015). Moreover, it is also believed that the sulfite added to the $\mathrm{V} 1$ sample may have acted as an antioxidant. V4 samples also showed relatively high antioxidant activity due to the addition of sulfite (refer to Table 1) (Jeong \& Cha, 2016).

During the storage period, no clear trend was observed in DPPH radical scavenging activity in $\mathrm{V} 1, \mathrm{~V} 2$ and $\mathrm{V} 3$, while it decreased in V4 and V5 to $78.44 \%$ and $58.35 \%$, respectively, after $12 \mathrm{mo}$. V4 tended to decrease to $77.97 \%$ after $3 \mathrm{mo}$, but V1 retained its antioxidant activity (85.47\%) even after 12 mo. Antioxidative activities in V1, V2, and V3 may rely on resveratrol and vitamin $\mathrm{C}$ in the grapes since their grape contents were $80 \%$ or more (V1: $99 \%$, V2: $90 \%$ and V3: 80\%, refer to Table 1). On the other hand, V4 showed lower antioxidative activity due to its lower grape content and consequently, lower resveratrol or vitamin C levels.

For the FRAP assay, an oxidation-reduction reaction, the reducing power was highest in $\mathrm{V} 4$ unlike the DPPH radical scavenging activity (Table 3). Lee et al. (2009) measured the antioxidative activities of vinegars retailed in Korea and reported that polyphenols and flavonoids were the major vinegar components involved in its antioxidant activities. Moreover, balsamic vinegars showed the highest antioxidative activity. Our results also supported that $\mathrm{V} 1$ and $\mathrm{V} 4$ showed higher antioxidative activities similarly to those of the balsamic vinegars in Lee et al. (2009). They also reported that antioxidant activities of vinegars might differ depending on biochemical characteristics or the type of antioxidants used.

\subsection{Descriptive analysis}

Sensory characteristics, which did not show significant interactions between sample and storage period, are summarized in Tables 4 and 5. All aromatics (grape, alcohol, yeast and nuruk flavor), except caramel, decreased after 12-mo storage compared to their initial values. This result may be due to the evaporation of volatile components in vinegars during 12 mo storage. There was no negative rancid flavor of vinegars after 12 mo long-term storage.

Vinegar flavor did not show any significant change in relation to storage period, but the bitterness became stronger as storage proceeded, possibly due to the oxidation of tannic acid in the grapes (Lee \& No, 2001). Grape flavor decreased significantly after 12 -mo storage, and was thought to be due to the strong bitter flavor which masked grape flavor. Decreased alcohol flavor after 12-mo storage may be due to reduced alcohol. There was no significant difference in texture characteristics in relation to storage period, suggesting that texture did not play an important role in dictating the quality of grape vinegars during long-term storage.

Table 5 shows that V4 and V5 were significantly different from other samples in that sweetness was relatively strong due to the presence of liquid fructose or high concentration of grape concentrates in these samples.

The strongest caramel and grape flavors were also recorded for $\mathrm{V} 4$ and $\mathrm{V} 5$, while sourness and bitterness were relatively lower (Min et al., 2002) reported a correlation between sweetness, sourness, and bitterness of food. In case where sweetness was

Table 4. Descriptive analysis of grape vinegars across sample.

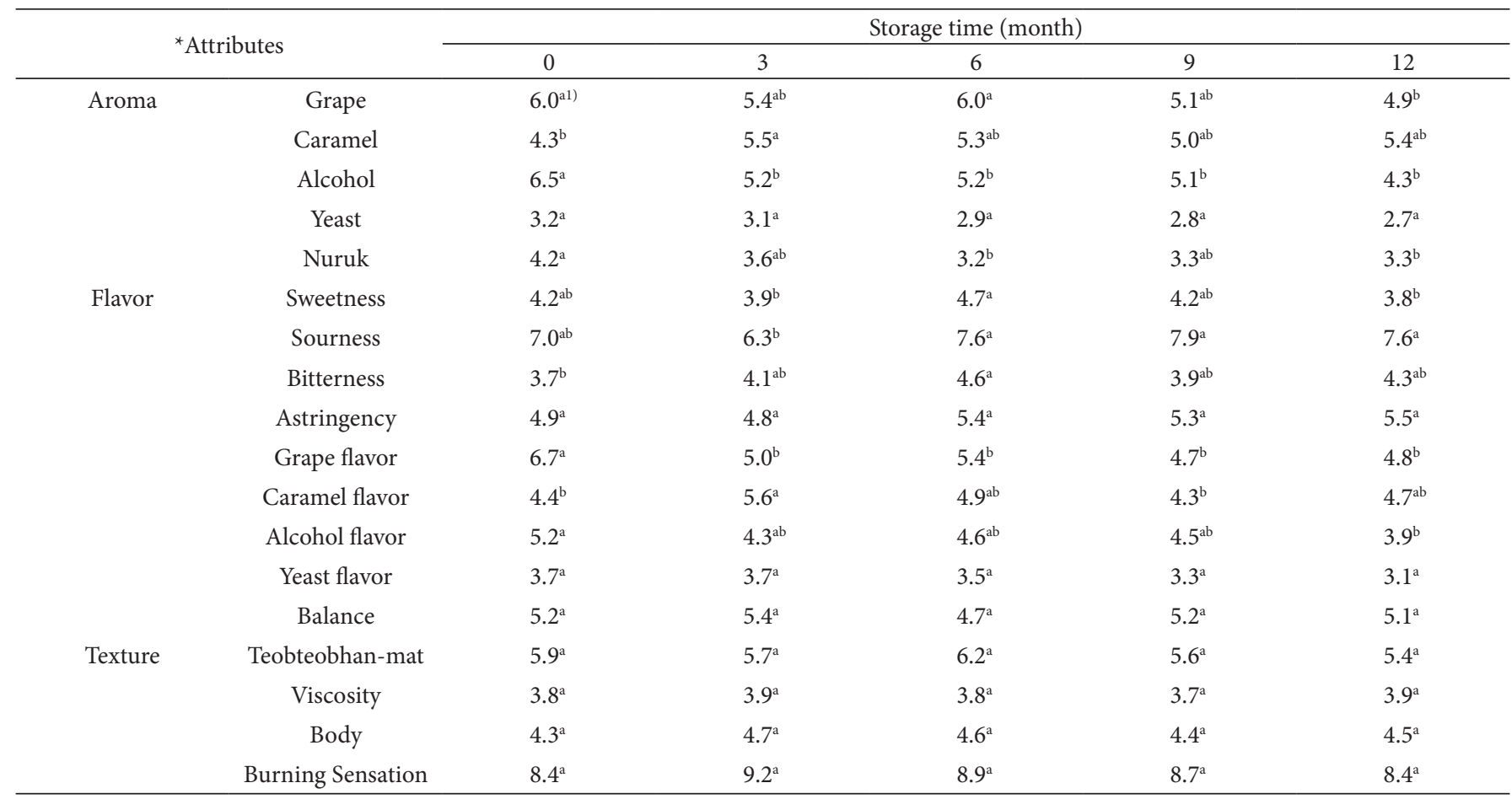

Product codes are the same as in Table 1. Balance: Overall degree of harmony; ${ }^{\star}$ No significant difference was observed for interactions between samples and storage time by ANOVA;

${ }^{1)}$ Different letters in the same row are significantly different $(\mathrm{p}<0.05)$. 
Table 5. Descriptive analysis of grape vinegars across storage times.

\begin{tabular}{|c|c|c|c|c|c|c|}
\hline \multirow{2}{*}{\multicolumn{2}{|c|}{${ }^{\star}$ Attributes }} & \multicolumn{5}{|c|}{ Sample } \\
\hline & & \multirow{2}{*}{$\frac{\mathrm{V} 1}{4.5^{\mathrm{c} 1)}}$} & \multirow{2}{*}{$\frac{\mathrm{V} 2}{4.9^{\mathrm{bc}}}$} & \multirow{2}{*}{$\frac{\mathrm{V} 3}{5.4^{\mathrm{bc}}}$} & \multirow{2}{*}{$\frac{\mathrm{V} 4}{6.8^{\mathrm{a}}}$} & \multirow{2}{*}{$\frac{\mathrm{V} 5}{5.8^{\mathrm{at}}}$} \\
\hline Aroma & Grape & & & & & \\
\hline & Caramel & $4.2^{\mathrm{b}}$ & $4.1^{\mathrm{b}}$ & $4.2^{\mathrm{b}}$ & $7.0^{\mathrm{a}}$ & $5.9^{\mathrm{a}}$ \\
\hline & Alcohol & $5.0^{\mathrm{bc}}$ & $5.6^{\mathrm{b}}$ & $8.0^{\mathrm{a}}$ & $3.3^{\mathrm{d}}$ & $4.4^{\mathrm{c}}$ \\
\hline & Yeast & $3.3^{\mathrm{a}}$ & $3.3^{\mathrm{a}}$ & $3.7^{\mathrm{a}}$ & $2.1^{\mathrm{b}}$ & $2.3^{\mathrm{b}}$ \\
\hline & Nuruk & $4.0^{\mathrm{a}}$ & $4.0^{\mathrm{a}}$ & $3.8^{\mathrm{ab}}$ & $2.5^{\mathrm{c}}$ & $3.2^{\mathrm{bc}}$ \\
\hline \multirow[t]{9}{*}{ Flavor } & Sweetness & $2.4^{\mathrm{c}}$ & $2.1^{\mathrm{c}}$ & $2.7^{\mathrm{c}}$ & $7.5^{\mathrm{a}}$ & $6.1^{\mathrm{b}}$ \\
\hline & Sourness & $8.2^{\mathrm{ab}}$ & $8.5^{\mathrm{a}}$ & $7.5^{\mathrm{b}}$ & $5.7^{c}$ & $6.6^{c}$ \\
\hline & Bitterness & $5.0^{\mathrm{a}}$ & $5.1^{\mathrm{a}}$ & $5.0^{\mathrm{a}}$ & $2.6^{\mathrm{b}}$ & $2.9^{\mathrm{b}}$ \\
\hline & Astringency & $5.9^{\mathrm{a}}$ & $6.0^{\mathrm{a}}$ & $5.8^{\mathrm{a}}$ & $4.0^{\mathrm{b}}$ & $4.2^{\mathrm{b}}$ \\
\hline & Grape flavor & $3.8^{\mathrm{d}}$ & $3.6^{\mathrm{d}}$ & $4.9^{c}$ & $7.8^{\mathrm{a}}$ & $6.4^{\mathrm{b}}$ \\
\hline & Caramel flavor & $2.6^{\mathrm{c}}$ & $2.8^{\mathrm{c}}$ & $2.9^{c}$ & $8.4^{\mathrm{a}}$ & $7.1^{\mathrm{b}}$ \\
\hline & Alcohol flavor & $5.1^{\mathrm{b}}$ & $5.0^{\mathrm{b}}$ & $6.4^{\mathrm{a}}$ & $2.8^{\mathrm{c}}$ & $3.1^{\mathrm{c}}$ \\
\hline & Yeast flavor & $4.1^{\mathrm{b}}$ & $3.8^{\mathrm{b}}$ & $4.9^{\mathrm{a}}$ & $2.2^{c}$ & $2.4^{\mathrm{c}}$ \\
\hline & Balance & $3.9^{\mathrm{b}}$ & $4.0^{\mathrm{b}}$ & $3.7^{\mathrm{b}}$ & $6.8^{\mathrm{a}}$ & $7.2^{\mathrm{a}}$ \\
\hline \multirow[t]{4}{*}{ Texture } & Teobteobhan-mat & $6.3^{\mathrm{a}}$ & $6.2^{\mathrm{a}}$ & $6.1^{\mathrm{a}}$ & $4.9^{\mathrm{b}}$ & $5.2^{\mathrm{b}}$ \\
\hline & Viscosity & $3.0^{\mathrm{b}}$ & $3.0^{\mathrm{b}}$ & $2.8^{\mathrm{b}}$ & $5.3^{\mathrm{a}}$ & $5.2^{\mathrm{a}}$ \\
\hline & Body & $3.8^{\mathrm{b}}$ & $3.8^{\mathrm{b}}$ & $3.5^{\mathrm{b}}$ & $5.8^{\mathrm{a}}$ & $5.7^{\mathrm{a}}$ \\
\hline & Burning Sensation & $9.8^{\mathrm{a}}$ & $9.7^{\mathrm{a}}$ & $9.3^{\mathrm{a}}$ & $7.0^{\mathrm{b}}$ & $7.8^{\mathrm{b}}$ \\
\hline
\end{tabular}

Product codes are the same as in Table 1. Balance: Overall degree of harmony; ${ }^{\star}$ No significant difference was observed for interactions between samples and storage time by ANOVA; ${ }^{1)}$ Different letters in the same row are significantly different $(\mathrm{p}<0.05)$.

stronger than sourness or bitterness (V4, V5), sourness and bitterness might be masked due to the strong sweetness. It was thought that astringency, alcohol and yeast flavors were also found to be lower in V4 and V 5 for the same reason. The strong grape flavor in $\mathrm{V} 4$ and $\mathrm{V} 5$ products may be due to the addition of high amounts of grape concentrate and artificial grape flavor added to these samples. Viscosity and body texture were also higher in V4 and V5, also attributed to the grape concentrates added to the samples (Batu et al., 2014).

\section{Conclusions}

The overall quality characteristics of commercial grape vinegars during long-term storage of 12 mo was found to vary significantly. The most marked changes in quality of grape vinegars was found after 6 mo of storage. Samples tended to be brown as storage peroids progressed, while antioxidant activities of samples decreased after $6 \mathrm{mo}$ of storage. Such sensory attributes as browning and turbidity was markedly elevated during 12-mo storage. Aromatic sensory characterisitcs were significantly attenuated in all test samples during storage because they are volatile compounds. Based on the results, it was suggested that commercial grape vinegars are best consumed within 6 mo of storage after opening.

\section{Acknowledgements}

This research was supported by the research fund of Dankook Univ. in 2018.

\section{References}

Ali, H. M., El-Gizawy, A. M., El-Bassiouny, R. E., \& Saleh, M. A. (2015). Browning inhibition mechanisms by cysteine, ascorbic acid and citric acid, and identifying PPO-catechol-cysteine reaction products. Journal of Food Science and Technology, 52(6), 3651-3659. PMid:26028748.

Ashchyan, H., Jen, M., Elenitsas, R., \& Rubin, A. I. (2018). Surreptitious apple cider vinegar treatment of a melanocytic nevus: newly described histologic features. Journal of Cutaneous Pathology, 45(4), 307-309. http://dx.doi.org/10.1111/cup.13102. PMid:29393529.

Atik, D., Atik, C., \& Karatepe, C. (2016). The effect of external apple vinegar application on varicosity symptoms, pain, and social appearance anxiety: a randomized controlled trial. Evidence-Based Complementary and Alternative Medicine, 2016, 6473678. http:// dx.doi.org/10.1155/2016/6473678. PMid:26881006.

Batu, A., Arslan, A., \& Eroğlu, A. (2014). Effects of black grape syrup on texture, colour and sensory qualies of value added Turkish Delight (Lokum). Journal of Nutrition \& Food Sciences, 6, 1-9. http://dx.doi. org/10.4172/2155-9600.S8-005.

Beh, B. K., Mohamad, N. E., Yeap, S. K., Ky, H., Boo, S. Y., Chua, J. Y. H., Tan, S. W., Ho, W. Y., Sharifuddin, S. A., Long, K., \& Alitheen, N. B. (2017). Anti-obesity and anti-inflammatory effects of synthetic acetic acid vinegar and Nipa vinegar on high-fat-diet-induced obese mice. Scientific Reports, 7(1), 6664. http://dx.doi.org/10.1038/ s41598-017-06235-7. PMid:28751642.

Budak, N. H., Aykin, E., Seydim, A. C., Greene, A. K., \& Guzel-Seydim, Z. B. (2014). Functional properties of vinegar. Journal of Food Science, 79(5), R757-R764. http://dx.doi.org/10.1111/1750-3841.12434. PMid:24811350.

Casale, M., Sáiz Abajo, M.-J., González Sáiz, J.-M., Pizarro, C., \& Forina, M. (2006). Study of the aging and oxidation processes of vinegar samples from different origins during storage by near-infrared spectroscopy. Analytica Chimica Acta, 557(1-2), 360-366. http:// dx.doi.org/10.1016/j.aca.2005.10.063.

Chen, F., Li, L., Qu, J., \& Chen, C. (2009). Cereal vinegars made by solid-state fermentation in China (pp. 243-259). Milano: Springer. http://dx.doi.org/10.1007/978-88-470-0866-3_15. 
Chen, H., Chen, T., Giudici, P., \& Chen, F. (2016). Vinegar functions on health: constituents, sources, and formation mechanisms. Comprehensive Reviews in Food Science and Food Safety, 15(6), 1124-1138. http://dx.doi.org/10.1111/1541-4337.12228.

Choi, E.-H., Kim, D.-S., Choi, S.-K., \& Park, K.-B. (2013). Optimization and quality characteristics of balsamic vinegar jelly with various gelling agents. The Korean Journal of Culinary Research, 19, 151-163.

Goswami, S., \& Ray, S. (2011). Studies on the process development for the fermentative production of wine from grape juice concentrate. Internet Journal of Food Safety, 13, 367-373.

Halima, B. H., Sonia, G., Sarra, K., Houda, B. J., Fethi, B. S., \& Abdallah, A. (2018). Apple cider vinegar attenuates oxidative stress and reduces the risk of obesity in high-fat-fed male wistar rats. Journal of Medicinal Food, 21(1), 70-80. http://dx.doi.org/10.1089/ jmf.2017.0039. PMid:29091513.

Hutchinson, U. F., Ntwampe, S. K. O., Ngongang, M. M., Chidi, B. S., Hoff, J. W., \& Jolly, N. P. (2019). Product and microbial population kinetics during balsamic-styled vinegar production. Journal of Food Science, 84(3), 572-579. http://dx.doi.org/10.1111/1750-3841.14429. PMid:30690746.

Ishak, I., George, P., Ibrahim, F. W., Yahya, H. M., \& Fara, N. (2018). Acute modulatory effects of apple cider vinegar, garlic, ginger, lemon and honey mixture, with and without exercise on postprandial glycemia in non-diabetic females. Journal of Health Sciences, 16, 105-111. http://dx.doi.org./10.17576/JSKM-2018-15.

Jeong, E. J., \& Cha, Y. J. (2016). Development of an onion vinegar beverage containing Yuza (Citrus junos Siebex Tanaka) and its biological activity. Journal of Life Science, 26(5), 563-570. http:// dx.doi.org/10.5352/JLS.2016.26.5.563.

Jeong, E. J., Jeon, S. Y., Baek, J. H., \& Cha, Y. J. (2011). Volatile flavor compounds in commercial vinegar beverages derived from fruits. Journal of Life Science, 21(2), 292-299. http://dx.doi.org/10.5352/JLS.2011.21.2.292.

Jeoung, Y.-J., \& Lee, M.-H. (2000). A view and prospect of vinegar industry. Food Industry Nutrition, 5(1), 7-12.

Jo, D., Park, E. J., Kim, G. R., Yeo, S. H., Jeong, Y. J., \& Kwon, J. H. (2012). Quality comparison of commercial cider vinegars by their acidity levels. Korean Journal of Food Science Technology, 44(6), 669-703. http://dx.doi.org/10.9721/KJFST.2012.44.6.699.

Kim, B. E., Turski, M. L., Nose, Y., Casad, M., Rockman, H. A., \& Thiele, D. J. (2010a). Cardiac copper deficiency activates a systemic signaling mechanism that communicates with the copper acquisition and storage organs. Cell Metabolism, 11(5), 353-363. http://dx.doi. org/10.1016/j.cmet.2010.04.003. PMid:20444417.

Kim, G. R., Yoon, S. R., Lee, J. H., Yeo, S. H., Jeong, Y. J., Young, Y. K., \& Kwon, J. H. (2010b). Physicochemical properties of and volatile components in commercial fruit vinegars. Korean Journal of Food Preservation., 17, 616-624.

Korea Agro-Fisheries and Food Trade Corporation - AT FIS. (2017). Processed food subdivision market status. Naju: AT FIS. Retrieved from https://atfis.or.kr/home/M000000000/index.do

Lee, M. H., \& No, H. K. (2001). Clarification of persimmon vinegar using chitosan. Journal of Korea Society of Food Science and Nutrition., 30, 277-282.

Lee, S. M., Choi, Y. M., Kim, Y. W., Kim, D. J., \& Lee, J. S. (2009). Antioxidant activity of vinegars commercially available in Korean markets. Food Engineering Progress, 13, 221-225.
Leiva, G. E., Naranjo, G. B., \& Malec, L. S. (2017). A study of different indicators of Maillard reaction with whey proteins and different carbohydrates under adverse storage conditions. Food Chemistry, 215, 410-416. http://dx.doi.org/10.1016/j.foodchem.2016.08.003. PMid:27542493.

Li, H., Guo, A., \& Wang, H. (2008). Mechanisms of oxidative browning of wine. Food Chemistry, 108(1), 1-13. http://dx.doi.org/10.1016/j. foodchem.2007.10.065.

Liu, F., He, Y., \& Wang, L. (2008). Comparison of calibrations for the determination of soluble solids content and $\mathrm{pH}$ of rice vinegars using visible and short-wave near infrared spectroscopy. Analytica Chimica Acta, 610(2), 196-204. http://dx.doi.org/10.1016/j.aca.2008.01.039. PMid:18291129.

Liu, Q., Li, X., Sun, C., Wang, Q., Yao, H., Yang, W., \& Wu, X. (2019). Effects of mixed cultures of Candida tropicalis and aromatizing yeast in alcoholic fermentation on the quality of apple vinegar. 3 Biotech, 9(4), 128.

Ma, L., \& Waterhouse, A. L. (2018). Flavanols react preferentially with quinones through an electron transfer reaction, stimulating rather than preventing wine browning. Analytica Chimica Acta, 1039, 162171. http://dx.doi.org/10.1016/j.aca.2018.07.013. PMid:30322547.

Mas, A., Torija, M. J., García-Parrilla, M. D. C., \& Troncoso, A. M. (2014). Acetic acid bacteria and the production and quality of wine vinegar. The Scientific World Journal, 2014, 1-6. http://dx.doi. org/10.1155/2014/394671. PMid:24574887.

Mensor, L. L., Menezes, F. S., Leitão, G. G., Reis, A. S., Santos, T. C., Coube, C. S., \& Leitão, S. G. (2001). Screening of Brazilian plant extracts for antioxidant activity by the use of DPPH free radical method. Phytotherapy Research, 15(2), 127-130. http://dx.doi. org/10.1002/ptr.687. PMid:11268111.

Min, S. H., Park, H. O., \& Oh, H. S. (2002). A Study on the properties of hot water extracts of Korean dried tangerine peel and development of beverage by using it. Korean Journal of Food and Cookery Science, 18(1), 51-56.

Mitrou, P., Petsiou, E., Papakonstantinou, E., Maratou, E., Lambadiari, V., Dimitriadis, P., Spanoudi, F., Raptis, S. A., \& Dimitriadis, G. (2015). Vinegar consumption increases insulin-stimulated glucose uptake by the forearm muscle in humans with type 2 diabetes. Journal of Diabetes Research, 2015, 175204. http://dx.doi.org/10.1155/2015/175204. PMid:26064976.

Mo, H.-W., Jung, Y.-H., Jeong, J.-S., Choi, K.-H., Choi, S.-W., Park, C.-S., Choi, M.-A., Kim, M.-L., \& Kim, M.-S. (2013). Quality Characteristics of Vinegar Fermented Using Omija (Schizandra chinensis Baillon). Journal of the Korean Society of Food Science and Nutrition, 42(3), 441-449. http://dx.doi.org/10.3746/jkfn.2013.42.3.441.

Mohamad, N. E., Yeap, S. K., Ky, H., Ho, W. Y., Boo, S. Y., Chua, J., Beh, B. K., Sharifuddin, S. A., Long, K., \& Alitheen, N. B. (2017). Dietary coconut water vinegar for improvement of obesity-associated inflammation in high-fat-diet-treated mice. Food \& Nutrition Research, 61(1), 1368322. http://dx.doi.org/10.1080/16546628.201 7.1368322. PMid:29056887.

Oh, H., Jang, S., Jun, H.-I., Jeong, D.-Y., Kim, Y.-S., \& Song, G.-S. (2017). Production of concentrated blueberry vinegar using blueberry juice and its antioxidant and antimicrobial activities. Journal of the Korean Society of Food Science and Nutrition, 46(6), 695-702.

Petsiou, E. I., Mitrou, P. I., Raptis, S. A., \& Dimitriadis, G. D. (2014). Effect and mechanisms of action of vinegar on glucose metabolism, 
lipid profile, and body weight. Nutrition Reviews, 72(10), 651-661. http://dx.doi.org/10.1111/nure.12125. PMid:25168916.

Roda, A., Lucini, L., Torchio, F., Dordoni, R., De Faveri, D. M., \& Lambri, M. (2017). Metabolite profiling and volatiles of pineapple wine and vinegar obtained from pineapple waste. Food Chemistry, 229, 734-742. http://dx.doi.org/10.1016/j.foodchem.2017.02.111. PMid:28372238.

Seo, K. I., Lee, J., Choi, R. Y., Lee, H. I., Lee, J. H., Jeong, Y. K., Kim, M. J., \& Lee, M. K. (2014). Anti-obesity and anti-insulin resistance effects of tomato vinegar beverage in diet-induced obese mice. Food \& Function, 5(7), 1579-1586. http://dx.doi.org/10.1039/c4fo00135d. PMid:24867606.

Thaipong, K., Boonprakob, U., Crosby, K., Cisneros-Zevallos, L., \& Hawkins Byrne, D. (2006). Comparison of ABTS, DPPH, FRAP, and ORAC assays for estimating antioxidant activity from guava fruit extracts. Journal of Food Composition and Analysis, 19(6-7), 669-675. http://dx.doi.org/10.1016/j.jfca.2006.01.003.

Torri, L., Jeon, S. Y., Piochi, M., Morini, G., \& Kim, K. O. (2017). Consumer perception of balsamic vinegar: A cross-cultural study between Korea and Italy. Food Research International, 91, 148-160. http://dx.doi.org/10.1016/j.foodres.2016.12.003. PMid:28290319.

Yang, H. S., \& Rho, J. O. (2012). The physiochemical characteristic and descriptive sensory evaluation of the blackberry fruit beverage. Korean Journal of Human Ecology., 21(2), 363-375. http://dx.doi. org/10.5934/KJHE.2012.21.2.363.

Zhang, B., Cai, J., Duan, C. Q., Reeves, M. J., \& He, F. (2015). A review of polyphenolics in oak woods. International Journal of Molecular Sciences, 16(4), 6978-7014. http://dx.doi.org/10.3390/ijms16046978. PMid:25826529. 